\title{
講演 4
}

\section{小細胞肺癌治療の最新トレンド 保保誠治}

索引用語—— 小細胞肺癌, アテゾリズマブ, デュルバルマブ

\section{はじめに}

分子標的薬および免疫チェックポイント阻害薬の臨床 導入により, 進行非小細胞肺癌の治療成績は飛躍的に向 上し，長期生存が期待されるようになってきた。一方， 小細胞肺癌 (SCLC) に対する有効な分子標的薬は開発が 進まず, 殺細胞性抗癌薬が進展型 SCLC 治療の中心を 担ってきた。 2019 年本邦において進展型 SCLC に対し PD-L1 抗体であるアテゾリズマブ, 2020 年にはデュルバ ルマブの適応が追加され, 化学療法と免疫チェックポイ ント阻害薬の併用が進展型 SCLCにおいても標準治療 となった.

\section{1. 限局型小細胞肺癌}

臨床病期 I IIA 期, すなわち腫瘍径が $5 \mathrm{~cm}$ 以下で縦 隔・肺門リンパ節転移, 遠隔転移を有さないSCLCに対 しては, 外科切除後, 補助化学療法が行われる. 完全切 除された病理病期 I IIIA 期の高悪性度神経内分泌肺癌 (SCLC および大細胞神経内分泌肺癌) に対するシスプラ チン +エトポシドとシスプラチン +イリノテカン併用療 法の比較試験 (JCOG1205/1206) では, 3 年無再発生存割 合がそれぞれ 65.4\%，69.0\%，ハザード比(HR) 1.076(95\% 信頼区間 $(\mathrm{CI}) ： 0.666$ 1.738) と有意差がなく，シスプラ チン +エトポシド併用療法が標準治療とされた. 1

臨床病期 IIB〜IIIB 期の SCLC に対しては, シスプラ チン+エトポシド併用療法, 同時胸部放射線治療（1回 1.5 G, 1 日 2 回, 計 30 回の加速多分割照射) が標準治療 であり, 完全奏効が得られれば, 予防的全脳照射が行わ れる。

\section{2. 進展型小細胞肺癌}

70 歳以下, PS 0-2 の進展型 SCLC に対して, シスプラ チン+エトポシドとシスプラチン +イリノテカン併用療 法の比較試験（JCOG9511）が行われ, 全生存期間 (OS) 中央值が 12.8 力月対 9.4 力月, $\mathrm{P}=0.002$ と有意差が見ら れ, シスプラチン +エトポシド併用療法が本邦における 進展型 SCLC に対する標準治療とされた. ${ }^{2}$ その後, 70 歳以下, PS 0-1 の進展型 SCLC に対するシスプラチン+ イリノテカンとシスプラチン +アムルビシン併用療法の 比較試験（JCOG0509）が行われた. シスプラチン＋イリ ノテカン併用療法に対するシスプラチン+アムルビシン 併用療法の全生存期間における非劣性を検証する比較試 験であったが, OS 中央值が 17.7 力月対 15.0 力月, HR $1.43(95 \% \mathrm{CI}: 1.10$ 1.85)であり, シスプラチン+アムル ビシン併用療法が有意に劣る結果であった. 3 一方, 海外 で行われた, 進展型 SCLC に対するシスプラチン +エト ポシドとシスプラチン+イリノテカン併用療法の比較試 験では, OS に有意差は見られず, シスプラチン+エトポ シド併用療法が標準治療とされた. ${ }^{4-6}$

こうした中, 免疫チェックポイント阻害薬を用いた 2 つの国際共同治験が行われた (表 1). IMpower 133 は, PS 0-1 の進展型 SCLC を対象とし, カルボプラチン + エ

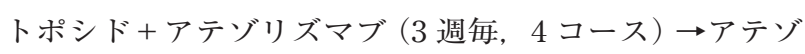
リズマブ (3 週毎) の維持療法とカルボプラチン＋エトポ シド+プラセボ (3 週毎, 4 コース) $\rightarrow$ プラセボ (3 週毎) の維持療法を比較する第 3 相試験である. 主要評価項目 は無増悪生存期間（PFS）と OS であった. OS 中央值は 12.3 力月対 10.3 力月, $\mathrm{HR} 0.70(95 \% \mathrm{CI}: 0.54 \sim 0.91), \mathrm{P}$ 
表 1. IMpower 133 と CASPIAN 試験の結果

\begin{tabular}{|c|c|c|c|c|c|}
\hline 試験名 & \multicolumn{2}{|c|}{ IMpower 133} & \multicolumn{3}{|c|}{ CASPIAN } \\
\hline 治療群 & $\begin{array}{c}\text { カルボプラチン+ } \\
\text { エトポシド+ } \\
\text { アテゾリズマブ }\end{array}$ & $\begin{array}{c}\text { カルボプラチン + } \\
\text { エトポシド+ } \\
\text { プラセボ }\end{array}$ & $\begin{array}{c}\text { プラチナ製剂*+ } \\
\text { エトポジ+ } \\
\text { デュルバルマブ }\end{array}$ & $\begin{array}{c}\text { プラチナ製剤*+ } \\
\text { エトポジ+ } \\
\text { デュルバルマブ+ } \\
\text { トレメリムマブ }\end{array}$ & $\begin{array}{l}\text { プラチナ製郕*+ } \\
\text { エトポジド }\end{array}$ \\
\hline 症例数 & 201 & 202 & 268 & 268 & 269 \\
\hline $\begin{array}{l}\text { 全生存期間中央值（月） } \\
(95 \% \mathrm{CI})\end{array}$ & $12.3(10.8 \sim 15.9)$ & $10.3(9.3 \sim 11.3)$ & 12.9 & 10.4 & 10.5 \\
\hline ハザード比 (95\%CI) & $0.70(0.54 \sim 0.91)$ & & $0.75(0.62 \sim 0.91)$ & $0.82(0.68 \sim 1.00)$ & \\
\hline 2 年生存割合 (\%) (95\%CI) & NR & NR & $22.2(17.3 \sim 27.5)$ & $23.4(18.4 \sim 28.8)$ & $14.4(10.3 \sim 19.2)$ \\
\hline $\begin{array}{l}\text { 無増覀生存期間中央值 (月) } \\
(95 \% \mathrm{CI})\end{array}$ & $5.2(4.4 \sim 5.6)$ & $4.3(4.2 \sim 4.5)$ & $5.1(4.7 \sim 6.2)$ & $4.8(4.7 \sim 5.9)$ & $5.4(4.8 \sim 6.2)$ \\
\hline ハザード比（95\%CI） & \multicolumn{2}{|c|}{$0.77(0.62 \sim 0.96)$} & $0.80(0.66 \sim 0.96)$ & $0.84(0.70 \sim 1.01)$ & \\
\hline $\begin{array}{l}2 \text { 年無増悪生存割合（\%) } \\
(95 \% \mathrm{CI})\end{array}$ & NR & NR & $11.0(7.5 \sim 15.2)$ & $11.5(7.9 \sim 15.8)$ & $2.9(1.2 \sim 5.8)$ \\
\hline 奏効割合（\%） & 63.7 & 65.4 & 68 & 58 & 58 \\
\hline
\end{tabular}

表 2. IMpower133 と CASPIAN 試験の治療法の違い

\begin{tabular}{|c|c|c|}
\hline 試験名 & IMpower 133 & CASPIAN \\
\hline 化学療法レジメン & カルボプラチン＋エトポシド & $\begin{array}{c}\text { シスプラチン+エトポシド，または } \\
\text { カルボプラチン+エトポシド }\end{array}$ \\
\hline 抗癌剤の投与量 & $\begin{array}{l}\text { カルボプラチン AUC } 5 \\
\text { エトポシド } 100 \mathrm{mg} / \mathrm{m}^{2}\end{array}$ & $\begin{array}{c}\text { シスプラチン } 75 \sim 80 \mathrm{mg} / \mathrm{m}^{2} \\
\text { カルボプラチン AUC } 5 \sim 6 \\
\text { エトポシド } 80 \sim 100 \mathrm{mg} / \mathrm{m}^{2}\end{array}$ \\
\hline 維持療法 (PD-L1 抗体) の投与間隔 & 3 週 & 4 週 \\
\hline
\end{tabular}

$=0.007$ であり, アテゾリズマブ群が有意に良好であっ た. PFS 中央值は 5.2 カ月対 4.3 カ月, $\mathrm{HR} 0.77(95 \% \mathrm{CI}$, 0.62 0.96), $\mathrm{P}=0.02$ であり, PFS の有意水準である 0.005 を超えたため, 統計学的有意差はないと判断された. 7 観 察期間を追加した解析では，18 月 OS 割合は $34.0 \%$ 対 $21.0 \%$ であった。 また，腫瘍細胞や腫瘍浸潤リンパ球 における PD-L1 発現別に OS が解析されたが, PD-L1 発現の有無, 程度に関わらず, アテゾリズマブ群の OS, PFS は良好な傾向であった. 8

CASPIAN は, PS 0-1 の進展型 SCLC を対象とし, プラ チナ製剤(カルボプラチンまたはシスプラチン)+エトポ シド併用療法＋デュルバルマブ $(3$ 週毎, 4 コース $) \rightarrow$ ユ゙ュ ルバルマブ維持療法 (4 週毎), 化学療法+デュルバルマ ブ+トレメリムマブ (3 週毎, 4 コース $) \rightarrow$ ゴュバルマ ブ維持療法（4 週毎), 化学療法（3 週毎，6コース）の 3 群を比較する第 3 相試験である。主要評価項目はOS であった. トレメリムマブは未承認の CTLA-4 抗体であ る. 中間解析の結果, 化学療法 +デュルバルマブと化学 療法単独群で OS の差が見られ, 早期に結果が公表され た. OS 中央值は 13.0 力月対 10.3 カ月, HR 0.73(95\%CI : 0.591 0.909), $\mathrm{P}=0.0047$ と有意にデュルバルマブ群が良
好であった (中間解析時, $\mathrm{p}<0.0178$ であれば統計学的有 意の設定) .9 その後解析された化学療法+デュルバルマ ブ+トレメリムマブと化学療法単独群の比較では, OS 中央值が 10.4 力月対 10.5 力月, HR 0.82 (95\%CI : 0.68 1.00), $\mathrm{P}=0.045$ であり, 有意差はなかった $(\mathrm{p}<0.0418$ であれば, 統計学的有意差ありと判定). 化学療法 + デュ ルバルマブと化学療法単独群の PFS 中央值は 5.1 カ 対 5.4 カ月, $\mathrm{HR} 0.80(95 \% \mathrm{CI}: 0.66 \sim 0.96), 2$ 年 $\mathrm{PFS}$ 割合 は $11.0 \%(95 \% \mathrm{CI}: 7.5 \sim 15.2)$ 対 $2.9 \%$ (95\%CI : 1.2〜 5.8) であった. 10

$2 つ の$ 比較試験において化学療法にPD-L1 抗体を追 加することで OS が有意に延長することが示され, 進展 型 SCLC に対する新たな標準治療となった. IPpower133 と CASPIAN 試験の治療法の違いを表 2 にまとめた．使 用されたプラチナ製剤, 抗癌剤の投与量, 維持療法の間 隔に違いがある。

\section{終わりに}

進展型 SCLC に対して, プラチナ製剤 +エトポシドと 免疫チェックポイント阻害薬の併用療法が標準治療と なったが, 生存期間の上乗せは $2 \sim 3$ カ月程度であるこ 
と, 2 年 PFS 割合は $10 \%$ 程度であり, 非小細胞肺癌にお ける化学療法と免疫チェックポイント阻害薬の併用療法 より治療効果は劣っている.さらなる新規の治療開発, および免疫チェックポイント阻害薬の治療効果を予測す るバイオマーカーの開発が望まれる.

本論文内容に関連する著者の利益相反：仁保誠治〔日当・講 演料〕アストラゼネカ, ファイザー, 中外製薬, 〔研究費・助 成金などの総額了アストラゼネカ, メルクセローノ, 中外製薬, 〔奨学 (奨励) 寄附金などの総額〕小野薬品, 大鵬薬品, 中外 製薬, 日本イーライリリー

\section{REFERENCES}

1. Kenmotsu H, Niho S, Tsuboi M, Wakabayashi M, Ishii G, Nakagawa K, et al. Randomized Phase III Study of Irinotecan Plus Cisplatin Versus Etoposide Plus Cisplatin for Completely Resected High-Grade Neuroendocrine Carcinoma of the Lung: JCOG1205/1206. J Clin Oncol. 2020;38:4292-4301.

2. Noda K, Nishiwaki Y, Kawahara M, Negoro S, Sugiura T, Yokoyama A, et al. Irinotecan plus cisplatin compared with etoposide plus cisplatin for extensive small-cell lung cancer. N Engl J Med. 2002;346:85-91.

3. Satouchi M, Kotani Y, Shibata T, Ando M, Nakagawa K, Yamamoto N, et al. Phase III study comparing amrubicin plus cisplatin with irinotecan plus cisplatin in the treatment of extensive-disease small-cell lung cancer: JCOG 0509. J Clin Oncol. 2014;32:1262-1268.

4. Hanna N, Bunn PA Jr, Langer C, Einhorn L, Guthrie T Jr, Beck T, et al. Randomized phase III trial comparing irinotecan/cisplatin with etoposide/cisplatin in patients with previously untreated extensive-stage disease small- cell lung cancer. J Clin Oncol. 2006;24:2038-2043.

5. Lara PN Jr, Natale R, Crowley J, Lenz HJ, Redman MW, Carleton JE, et al. Phase III trial of irinotecan/cisplatin compared with etoposide/cisplatin in extensive-stage small-cell lung cancer: clinical and pharmacogenomic results from SWOG S0124. J Clin Oncol. 2009;27:2530-2535.

6. Zatloukal P, Cardenal F, Szczesna A, Gorbunova V, Moiseyenko V, Zhang X, et al. A multicenter international randomized phase III study comparing cisplatin in combination with irinotecan or etoposide in previously untreated small-cell lung cancer patients with extensive disease. Ann Oncol. 2010;21:1810-1816.

7. Horn L, Mansfield AS, Szczessna A, Havel L, Krzakowski M, Hochmair MJ, et al. First-Line Atezolizumab plus Chemotherapy in Extensive-Stage Small-Cell Lung Cancer. N Engl J Med. 2018;379:2220-2229.

8. Liu SV, Reck M, Mansfield AS, Mok T, Scherpereel A, Reinmuth N, et al. Updated Overall Survival and PD-L1 Subgroup Analysis of Patients With Extensive-Stage Small-Cell Lung Cancer Treated With Atezolizumab, Carboplatin, and Etoposide (IMpower133). J Clin Oncol. 2021;39:619-630.

9. Paz-Ares L, Dvorkin M, Chen Y, Reinmuth N, Hotta K, Trukhin D, et al. Durvalumab plus platinum-etoposide versus platinum-etoposide in first-line treatment of extensive-stage small-cell lung cancer (CASPIAN): a randomised, controlled, open-label, phase 3 trial. Lancet. 2019; 394:1929-1939.

10. Goldman JW, Dvorkin M, Chen Y, Reinmuth N, Hotta K, Trukhin D, et al. Durvalumab, with or without tremelimumab, plus platinum-etoposide versus platinum-etoposide alone in first-line treatment of extensive-stage small-cell lung cancer (CASPIAN): updated results from a randomised, controlled, open-label, phase 3 trial. Lancet Oncol. 2021;22:51-65.

\section{Current Trends in the Treatment of Small-cell Lung Cancer Treatment}

Seiji Niho1

${ }^{1}$ Department of Pulmonary Medicine and Clinical Immunology, Dokkyo Medical University. 